\title{
д.о. Дзюба
}

Національна медична академія післядипломної освіти імені П.Л. Шупика, Київ

\section{Інтраопераційна динаміка рівня інтерлейкіну-6 під час планового коронарного стентування за різних підходів до анальгоседації}

Мета роботи - дослідити в періопераційний період планового коронарного стентування динаміку рівня інтерлейкіну-6 (ІЛ-6) залежно від застосування різних препаратів для анальгоседації.

Матеріали і методи. Дослідження проведено в період з вересня 2018 р. до березня 2020 р. на базі дУ «Інститут серця МОЗ України» та К3 КОР «Київська обласна клінічна лікарня» за участю 90 пацієнтів з ішемічною хворобою серця. Хворих рівномірно розділили на три групи залежно від препаратів, якими було проведено інтраопераційну анальгоседацію: 1-ша група - повільне внутрішньовенне введення 10 мг розчину діазепаму та 100 мкг розчину фентанілу на індукцію і повторне введення цих препаратів у тій же дозі для підтримання анестезії протягом операції; 2-га група - повільне внутрішньовенне введення розчину фентанілу в дозі 1,5 мг/кг на індукцію та 1,5 мг/кг за 1 год для підтримання рівня анальгезії, для підтримання певного рівня седації використовували розчин пропофолу; 3-тя група - повільне внутрішньовенне введення розчину лідокаїну в дозі 1 мг/кг на індукцію, для седації - розчин пропофолу. Всім пацієнтам виконали реканалізацію в плановому порядку. Основним досліджуваним показником був рівень ІЛ-6 до оперативного втручання та через 10 хв після імплантації стента.

Результати. При порівнянні доопераційних показників з результатами, отриманими після стентування, в усіх групах рівень ІЛ-6 через 10 хв після імплантації стента був нижчим за доопераційний. При цьому статистично значущою різниця між досліджуваним показником до операції і через 10 хв після імплантації стента була в 2-й та 3-й групах, на відміну від такої у хворих 1-ї групи: рівень ІЛ-6 знизився на 30 \% у 2-й групі (p=0,005) та на 30 \% у 3-й групі $(p=0,001)$. Після стентування рівень ІЛ-6 у хворих 2-ї групи був нижчим, ніж у пацієнтів 1-ї групи, на $23 \%(p=0,153)$, у хворих 3-ї групи - на $31 \%(p=0,02)$ відповідно.

Висновки. Рівень прозапального ІЛ-6 при плановому стентуванні коронарних артерій має тенденцію до зниження після встановлення стента, при цьому нижчі показники спостерігалися в групах, в котрих використовували як анестетик розчин пропофолу. Слід відзначити, що в 3-й групі (де застосовували безопіатну анальгезію) рівень ІЛ-6 через 10 хв після імплантації стента був статистично значуще $(p=0,02)$ нижчим, ніж у 1-й групі, у той час як між 1-ю і 2-ю групами статистично значущої різниці за цим показником не спостерігали $(p=0,153)$. Цей факт можна пояснити застосуванням розчину лідокаїну в пацієнтів 3-ї групи.

Ключові слова: інтерлейкін-6, планове коронарне стентування, анальгоседація, ішемічна хвороба серця.

Посилання: Дзюба Д.О. Інтраопераційна динаміка рівня інтерлейкіну- 6 під час планового коронарного стентування за різних підходів до анальгоседації // Кардіохірургія та інтервенційна кардіологія.- 2020.- № 3.- С. 15-20.

To cite this article: Dziuba DO. Intraoperative dynamics of interleukin- 6 levels during planned coronary stenting with different approaches to analgesic sedation. Cardiac Surgery and Interventional Cardiology. 2020;3(30):15-20 (in Ukr.). 
$\mathbf{3}^{a}$ а даними статистичних досліджень останніх десятиліть, серцево-судинні захворювання (CC3) стоять на перших позиціях серед причин смертності в усьому світі, становлячи близько половини всіх причин смерті в Європі та США. Від ішемічної хвороби серця (IXC) та інсультів щороку помирають більше 4 млн осіб, та ще більша кількість пацієнтів потребує госпіталізації 3 тривалим лікуванням. Прямі й непрямі економічні втрати ЄС становлять більш ніж 210 млрд євро щорічно [4, 13]. За даними Американської асоціації серця (АНА) за 2020 р., 7,4 \% чоловіків та 6,2 \% жінок хворіють на IXC, а інфаркт міокарда виникає у 3 \% осіб віком понад 20 років. Шороку у США гострий інфаркт міокарда (ГІМ) реєструють у 605 тис. осіб, а повторний - у 200 тис. Середній вік пацієнтів з ГІМ становить 65,6 року для чоловіків і 72 роки для жінок [19]. На лікування СС3 у США витрачають щорічно близько 1,1 трлн доларів. В Україні частка ССЗ у структурі захворюваності населення також найбільша: понад 8 млн осіб мають СС3, причому у 12 тис. 3 них реєструють ГІМ, а загальна летальність від IXC у 2015 р. становила 433 на 100000 населення [1, 13].

Прозапальна реакція організму посідає особливе місце в патогенезі гострого коронарного синдрому. Під час гіпоксії погіршується цілісність ендотеліальних клітин, а також страждає їх бар'єрна функція, збільшується судинна проникність і підвищується інфільтрація лейкоцитів. При подовженні ішемічного періоду активуються механізми загибелі клітин паренхіми та кардіоміоцитів шляхом некрозу, а потім вторинно приєднується апоптоз. Некроз, пошкодження клітин серця та пошкодження позаклітинного матриксу вивільняють речовини, що відіграють роль сигналів небезпеки, які ініціюють імунну систему на захист клітин паренхіми та через інфільтрацію лейкоцитів сприяють потужній активації прозапальних медіаторів. У цій ролі виступають прозапальні цитокіни, хемокіни та молекули клітинної адгезї [14].

Під час ішемії міокарда найважливішими прозапальними цитокінами виступають інтерлейкін (IЛ) $1 \beta$, ІЛ-6 та фактор некрозу пухлини $\alpha$ (ФНП- $\alpha)$. ІЛ-1 є попередником прозапальних цитокінів та має назву ендогенний піроген за його властивість провокувати лихоманку. Одна 3 його форм - ІЛ-1 $\beta$, що активується каспазою-1. Він має короткий період напіврозпаду, визначається протягом перших 2 год після IM та корелює з об’ємом пошкодження міокарда. Основним вторинним маркером є ІЛ-6. Він продукується у відповідь на низку стимулів, одним iз яких виступає IЛ-1. Пік його продукції при- падає на першу добу пошкодження та корелює 3 його розміром. Ше одним прозапальним агентом є ФНП- $\alpha$. Він вивільняється клітинами при запаленні та корелює не лише з рівнем ураження міокарда, а й із систолічною функцію серця. Високий рівень цих цитокінів тісно пов'язаний з летальністю [16, 18].

Серед усіх методів лікування тяжких форм IXC одним із найперспективніших є перекутанні інтервенційні втручання. Наприклад, у США щорічно таких втручань виконують понад півмільйона [19]. Саме під час цих процедур вивчення динаміки прозапальних цитокінів становить особливу наукову цінність, тому що, незважаючи на розвиток рентгенендоваскулярної хірургії, частота виникнення ускладнень залишається достатньо високою, а процеси періопераційного запалення відіграють важливу роль, і їх визначення може вплинути як на оцінку ризику, так i на стратегії терапії IXC.

За даними досліджень останніх десятиліть, запалення відіграє ключову роль у патогенезі IXC. Виходячи 3 них, зрозуміло, що цитокіни Т-клітин під час декомпенсації цього захворювання вивільняють у кровоплин значну кількість IЛ-6. Його концентрація є не тільки діагностичним, а й прогностичним фактором. Цей показник виступає предиктором летальних наслідків від кардіальних причин. Його роль як агента, що дозволяє прогнозувати летальність, зумовлена не тільки прозапальними чи прокоагулянтними властивостями [20], а й тим, що поліморфізм гена $174 \mathrm{G}>\mathrm{C}$ та IL6R, з якими пов'язаний метаболізм IЛ-6, асоційований 3 ризиком летальності від CC3 $[5,6]$.

Ще на початку 1990-х років приділялося багато уваги патофізіології пролонгованої ішемії, що виникає під час ушкодження кардіоміоцитів. Особливого значення в імунологічних аспектах цього процесу надавали IЛ-6. Його підвищену продукцію відзначали разом з інфільтрацією нейтрофілів та макрофагів під час ГІМ, а підвищена концентрація в плазмі спостерігалася протягом 4 тиж цього захворювання [12].

Мета роботи - дослідити в періопераційний період планового коронарного стентування динаміку рівня інтерлейкіну-6 залежно від застосування різних препаратів для анальгоседації.

\section{Матеріали і методи}

Дослідження проведено в період 3 вересня 2018 р. до березня 2020 р. на базі ДУ «Інститут серця МО3 України» та КЗ КОР «Київська обласна клінічна лікарня» за участю 90 пацієнтів 3 IXC. 
Таблиця 1

Загальна характеристика груп дослідження

\begin{tabular}{lccc}
\hline Показник & 1-ша група $(\mathbf{n}=\mathbf{3 0})$ & 2-га група $(\mathbf{n}=\mathbf{3 0})$ & 3-тя група $(\mathbf{n}=\mathbf{3 0})$ \\
\hline Вік, роки & $62,2 \pm 10,6$ & $61,6 \pm 9,4$ & $63,4 \pm 7,9$ \\
\hline Чоловіки / Жінки & $21 / 9$ & $22 / 8$ & $23 / 7$ \\
\hline Індекс маси тіла, кг/м & $28,4 \pm 3,4$ & $28,6 \pm 4,4$ & $28,7 \pm 4,2$ \\
\hline Артеріальна гіпертензія & $26(86,6 \%)$ & $29(96,6 \%)$ & $27(90,0 \%)$ \\
\hline Гемоглобін, г/л & $136,1 \pm 16,6$ & $137,5 \pm 17,2$ & $136,3 \pm 19,2$ \\
\hline Гематокрит, \% & $41,1 \pm 2,7$ & $41,5 \pm 4,1$ & $41,7 \pm 4,6$ \\
\hline ХС лпнщ, ммоль/л & $3,2 \pm 0,6$ & $3,4 \pm 0,9$ & $3,4 \pm 0,7$ \\
\hline ХС лпВЩ, ммоль/л & $1,0 \pm 0,4$ & $1,1 \pm 0,3$ & $1,0 \pm 0,3$ \\
\hline
\end{tabular}

Категорійні показники наведено як кількість випадків і частка, кількісні - як М \pm б. ХС лпнщ - холестерин ліпопротеїнів низької щільності; ХС лпВЩ - холестерин ліпопротеїнів високої щільності.

Хворих рівномірно розділили на три групи дослідження залежно від препаратів, якими було проведено інтраопераційну анальгоседацію (AC). Усім пацієнтам було виконано черезшкірну реканалізацію в плановому порядку. Цільовим рівнем седації під час проведення стентування коронарних артерій був III за RAMSEY, що відповідає помірній седації. Пацієнтам 1-ї групи АС проводили повільним внутрішньовенним введенням 10 мг розчину діазепаму та 100 мкг розчину фентанілу на індукцію і повторним введенням вищезазначених препаратів у тому ж дозуванні для підтримання анестезії протягом оперативного втручання. У 2-й групі для анальгезії використовували повільне внутрішньовенне введення розчину фентанілу в дозі 1,5 мг/кг на індукцію та 1,5 мг/кг за 1 год для підтримання рівня анальгезії. Для підтримання певного рівня седації використовували розчин пропофолу в цільовій дозі отримання цільового рівня свідомості. У 3 -й групі використовували один із сучасних підходів до АС - безопіатну анестезію. Метод широко висвітлюється в наукових роботах останніх років і базується на ідеї, що уникнення застосування опіатів під час оперативних утручань корелює 3 кращими результатами лікування $[3,8,10,11]$. Так, для анальгезії в цій групі повільно внутрішньовенно вводили розчин лідокаїну в дозі 1 мг/кг на індукцію, а для седації використовували розчин пропофолу в цільовій дозі, щоб отримати рівень III за RAMSEY. Окрім клінічних ознак, рівень седації контролювали за допомогою BISмоніторингу.

Критеріями вилучення із дослідження були: вік понад 75 років, прогресивна ниркова недостатність, дисфункція печінки, гостра та хронічна інфекція, серцева недостатність, хірургічні втручання та травми протягом 3 міс, запалення, анемія, захворювання периферичних судин, підозри на системні тромботичні захворювання та вагітність, цукровий діабет і рак, інші захворювання серця, дисфункція щитоподібної залози та автоімунні захворювання.

Основним показанням до оперативного втручання в усіх групах дослідження була IXC: стенокардія напруження III функціонального класу. Пацієнти груп дослідження статистично значуще не відрізнялися за основними клінічними й антропометричними ознаками (табл. 1).

Основним досліджуваним показником був рівень ІЛ-6 до початку оперативного втручання та через 10 хв після імплантації стента. Під час дослідження у хворих забирали 3 мл венозної крові та протягом 30 хв усі зразки крові центрифугували при $4{ }^{\circ} \mathrm{C} 10$ хв (3000 об/хв). Сироватку зберігали при $-70{ }^{\circ} \mathrm{C}$ для проведення подальших досліджень.

Рівень ІЛ-6 оцінювали після отримання повної сукупності зразків. Концентрацію ІЛ-6 у сироватці (чутливість 2 пг/мл) визначали методом ELISA (Bio-Source Europe S.A., Nivelles, Бельгія).

Статистичне опрацювання даних проводили 3 використанням t-тесту Стьюдента або варіаційного аналізу; для порівняння даних застосовували тест $\chi^{2}$. Усі дані були проаналізовані з використанням програмного забезпечення Statistica 6.

\section{Результати та обговорення}

Показники періопераційного рівня IЛ-6 наведено в табл. 2. Так, на етапі до оперативного втручання не спостерігали статистично значущої різниці між групами дослідження.

При порівнянні доопераційних показників 3 результатами, отриманими після стентування, 
Таблиця 2

Рівень інтерлейкіну-6 при різних підходах до анальгоседації в періопераційний період планового стентування коронарних артерій $(n=90)$

\begin{tabular}{lccc}
\hline ІЛ-6, пг/мл & 1-ша група $(\mathbf{n}=\mathbf{3 0})$ & 2-га група $(\mathbf{n}=\mathbf{3 0})$ & 3-тя група $(\mathbf{n}=\mathbf{3 0})$ \\
\hline До ЧКВ & $5,75 \pm 1,98$ & $5,79 \pm 1,75$ & $5,19 \pm 2,19$ \\
\hline Через 10 хв & $5,28 \pm 3,02$ & $4,03 \pm 1,16 *$ & $3,65 \pm 1,82$ **\#
\end{tabular}

Різниця показників статистично значуща порівняно з такими до ЧКВ: * $p=0,005$ * * $p=0,001$. Різниця показників статистично значуща порівняно з такими в пацієнтів 1-ї групи: \# $p=0,02$. ЧКВ - черезшкірне коронарне втручання.

в усіх групах показники були нижчими за такі до операції. При цьому статистично значущою різниця між досліджуваним показником до операції і через 10 хв після імплантації стента була в 2-й та 3-й групах, на відміну від такої у хворих 1-ї групи: рівень ІЛ-6 знизився на $30 \%$ у 2-й групі $(\mathrm{p}=0,005)$ і на $30 \%$ у 3 -й групі $(\mathrm{p}=0,001)$. Це зниження показників можна пояснити позитивним впливом оперативного втручання, але 3 результатів дослідження помітно значну різницю саме в 2-й та 3-й групах.

Так, якщо порівнювати рівень ІЛ-6 після стентування між групами дослідження, то в 2-й групі його рівень був нижчий, ніж у 1-й групі, на $23 \%$ $(\mathrm{p}=0,153)$, а в 3-й групі - на $31 \%(\mathrm{p}=0,02)$. У медикаментозному забезпеченні основну відмінність становить застосування розчину пропофолу в обох групах дослідження, в яких виявлено статистично значущу різницю. За даними літератури, цей препарат пригнічує продукцію ІЛ-1 $\beta$, ІЛ-6 та ФНП- $\alpha$ різними типами клітин. Такий ефект виникає за рахунок того, що пропофол активує $\gamma$-амінобутирову кислоту типу А (GABAA). Кілька імунозалежних типів клітин викликають експресію GABAA. Це і моноцити, і макрофаги, і Т-клітини $[15,21]$. У низці праць останніх років підтверджено інгібувальний вплив цього препарату саме на IЛ-6 [9, 22].

Але привертає увагу, те що при порівнянні між групами післяопераційного рівня ІЛ-6 статистично значущу різницю відзначено між 1-ю групою і 3-ю групою, в якій, окрім пропофолу, як анальгетик застосовували безопіатну анестезію на основі розчину лідокаїну. Антизапальні властивості цього препарату загальновідомі. Він інгібує активацію лейкоцитів та їх адгезію на місце ушкодження як in vivo, так in vitro. Цей препарат охороняє клітини від запалення завдяки блокаді нейтрофілів та попереджуючи вивільнення вільних радикалів окиснення. Так, низкою досліджень доведено, що інтраопераційне введення лідокаїну суттєво обмежує інтраопераційне вивільнення прозапальних цитокінів, таких як IЛ-6 та IЛ-8 [2, 7, 17]. Тому можна підтвердити дані попередніх дослідників і частково пояснити зниження післяопераційного рівня IЛ-6 застосуванням розчинів пропофолу та лідокаїну.

\section{Висновки}

Рівень прозапального інтерлейкіну-6 при плановому стентуванні коронарних артерій має тенденцію до зниження після встановлення стента, при цьому нижчі показники спостерігалися в групах, в котрих використовували як анестетик розчин пропофолу. Різниця між досліджуваним показником до операції і через 10 хв після імплантації стента була статистично значущою в 2-й та 3-й групах, на відміну від такої у хворих 1-ї групи: рівень інтерлейкіну- 6 знизився на $30 \%$ у 2-й групі $(\mathrm{p}=0,005)$ і на $30 \%$ у 3-й групі $(\mathrm{p}=0,001)$.

Водночас у 3-й групі (де застосовували безопіатну анальгезію) рівень інтерлейкіну- 6 через 10 хв після імплантації стента був статистично значуще $(\mathrm{p}=0,02)$ нижчим, ніж у 1-й групі, у той час як між 1-ю і 2-ю групами статистично значущої різниці за цим показником не спостерігали $(\mathrm{p}=0,153)$. Цей факт можна пояснити застосуванням розчину лідокаїну в пацієнтів 3-ї групи.

Конфлікту інтересів немає. 


\section{Література}

1. Аксьонов Є.В. Рентген-ендоваскулярні процедури на тлі гострого інфаркту міокарда // Укр. журн. медицини, біології та спорту.- 2019.- № 6.- C. 104-109. doi: 10.26693/ jmbs04.06.104.

2. Beaussier M. et al. Perioperative use of intravenous lidocaine // Drugs.- 2018.- P. 1229-1246. doi: 10.1007/s40265-0180955-x.

3. Beloeil H. Opioid-free anesthesia // Best Practice and Research: Clinical Anaesthesiology.- 2019.- Vol. 33 (3).P. 353-360. doi: 10.1016/j.bpa.2019.09.002.

4. Benjamin E.J., Virani S.S., Callaway C.W. et al. Heart Disease and Stroke Statistics - 2018 Update: A Report From the American Heart Association // Circulation.- 2018.Vol.137(12).-P.67-492. doi: 10.1161/CIR.0000000000000558.

5. González-Castro T.B., Hernández-Díaz Y., Pérez-Hernández N. et al. Interleukin 6 (rs1800795) gene polymorphism is associated with cardiovascular diseases: a meta-analysis of 74 studies with 86,229 subjects // EXCLI J.- 2019.- Vol. 18.P. 331. doi: 10.17179/excli2019-1248.

6. Hansen P.R., Nelveg-Kristensen K.E., Rasmussen H.B. et al. Prognostic role of genetic polymorphisms of the interleukin- 6 signaling pathway in patients with severe heart failure // The Pharmacogenomics J.- 2019.- Vol. 19 (5).- P. 428-437. doi: 10.1038/s41397-019-0068-2.

7. Herroeder S., Pecher S., Schönherr M.E. et al. Systemic lidocaine shortens length of hospital stay after colorectal surgery: a doubleblinded, randomized, placebo-controlled trial // Ann. Surg.- 2007.- Vol. 246.- P. 192-200. doi: 10.1097/ SLA.0b013e31805dac11.

8. Hontoir S., Saxena S., Gatto P. et al. Opioid-free anesthesia: what about patient comfort? A prospective, randomized, controlled trial // Acta Anaesthesiol Belg.-2016.-Vol. 67 (4).P. 183-190. PMID: 29873988.

9. Kochiyama T. et al. Effect of propofol on the production of inflammatory cytokines human polarized macrophages // Mediators of Inflammation.- 2019. doi: 10.1155/2019/1919538.

10. Lavand'homme P., Arnaud S. Opioid-free anesthesia opioid side effects: tolerance and hyperalgesia // Best Practice \& Research: Clinical Anaesthesiology.- 2017.- P. 487-498. doi: 10.1016/j.bpa.2017.05.003

11. Mauermann E., Ruppen W., Bandschapp O. Different protocols used today to achieve total opioid-free general anesthesia without locoregional blocks // Best Practice \& Research: Clinical Anaesthesiology.- 2017.- P. 533-545. doi: 10.1016/j. bpa.2017.11.003.
12. Miyao Y. et al. Elevated plasma interleukin-6 levels in patients with acute myocardial infarction // Amer. Heart J.- 1993.P. 1299-1304. doi: 10.1111/j.1749-6632.1989.tb24040.x.

13. Movsisyan N.K., Vinciguerra M., Medina-Inojosa J.R., LopezJimenez F. Cardiovascular Diseases in Central and Eastern Europe: A Call for More Surveillance and Evidence-Based Health Promotion // Ann. Global Health.- 2020.- Vol. 86 (1). doi: 10.5334/aogh.2713.

14. Prabhu S.D., Frangogiannis N.G. The biological basis for cardiac repair after myocardial infarction: from inflammation to fibrosis // Circulation Research.- 2016.- Vol. 119 (1).P. 91-112. doi: 10.1161/CIRCRESAHA.116.303577.

15. Sanders R.D., Grover V., Goulding J. et al. Immune cell expression of GABAA receptors and the effects of diazepam on influenza infection // J. Neuroimmunology.- 2015.Vol. 282.- P. 97-103. doi: 10.1016/j.jneuroim.2015.04.001.

16. Seropian I.M., Sonnino C., Van Tassell B.W. et al. Inflammatory markers in ST-elevation acute myocardial infarction // Eur. Heart J.: Acute Cardiovascular Care.- 2016.- Vol. 5 (4).P. 382-395. doi: 10.1177/2048872615568965.

17. Sridhar P., Sistla S.C., Ali S.M. et al. Effect of intravenous lignocaine on perioperative stress response and post-surgical ileus in elective open abdominal surgeries: a double-blind randomized controlled trial // ANZ. J. Surg.- 2015.- Vol. 85.P. 425-429. doi: 10.1186/s13063-019-3677-9.

18. Stuart S.D.F., De Jesus N.M., Lindsey M.L., Ripplinger C.M. The crossroads of inflammation, fibrosis, and arrhythmia following myocardial infarction // J. Molecul. Cellul. Cardiology.2016.- Vol. 91.- P. 114-122. doi: 10.1016/j.yjmcc.2015.12.024.

19. Virani, S.S., Alonso A., Benjamin E.J. et al. Heart disease and stroke statistics - 2020 update: a report from the American Heart Association // Circulation.- 2020.- P. E139-E596. doi: 10.1161/CIR.0000000000000757.

20. Walter J., Tanglay Y., de Lavallaz J.D.F. et al. Clinical utility of circulating interleukin- 6 concentrations in the detection of functionally relevant coronary artery disease // Intern. J. Cardiology.- 2019.- Vol. 275.- P. 20-25. doi: 10.1016/j. ijcard.2018.10.029.

21. Wheeler D.W., Thompson A.J., Corletto F. et al. Anaesthetic impairment of immune function is mediated via GABAA receptors // PLoS One.- 2011.- Vol. 6 (2).- P. e17152. doi: 10.1371/journal.pone.0017152.

22. Zhang Hua-bin et al. Propofol Reduces Inflammatory Brain Injury after Subarachnoid Hemorrhage: Involvement of PI3K/Akt Pathway // J. Stroke Cerebrovasc. Diseases.- 2019.P. 104375. doi: 10.1016/j.jstrokecerebrovasdis.2019.104375.

\section{Д.А. Дзюба}

Национальная медицинская академия последипломного образования имени П.Л. Шупика, Киев

\section{Интраоперационная динамика уровня интерлейкина-6 во время планового коронарного стентирования при различных подходах к аналгоседации}

Цель работы - исследовать в периоперационный период планового коронарного стентирования динамику уровня интерлейкина-6 (ИЛ-6) в зависимости от различных препаратов для аналгоседации.

Материалы и методы. Исследование проводилось в период с сентября 2018 г. по март 2020 г. на базе гу «Институт сердца МЗ Украины» и К3 КОР «Киевская областная клиническая больница» при участии 90 пациентов с ишемической болезнью сердца. Пациенты были равномерно разделены на три группы в зависимости от препаратов, которыми проводилась интраоперационная аналгоседация: 1-я группа - медленное введение 10 мг раствора диазепама и 100 мкг раствора фентанила на индукцию и повторное введение этих препаратов в той же дозе для поддержания анестезии в течение операции; 2-я группа - медленное введение раствора фентанила в дозе 1,5 мг/кг на индукцию и 1,5 мг/кг в 1 ч для поддержания уровня анальгезии, для поддержания определенного уровня седации использовали раствор пропофола; 3-я группа - медленное введение раствора лидокаина в дозе 1 мг/кг на индукцию, для седации - раствор пропофола. Всем пациентам была выполнена реканализация в плановом порядке. Основным исследуемым показателем был уровень ИЛ-6 до оперативного вмешательства и через 10 мин после имплантации стента. 
Результаты. При сравнении операционных показателей с результатами, полученными после стентирования, во всех группах уровень ИЛ-6 через 10 мин после имплантации стента был ниже, чем до операции. Причем статистически значимой разница между исследуемым показателем до операции и через 10 мин после имплантации стента была во 2-й и 3-й группах, в отличие от таковой у больных 1-й группы: уровень ИЛ-6 снизился на 30 \% во 2-й группе $(p=0,005)$ и на 30 \% в 3-й группе $(p=0,001)$. После стентирования уровень ИЛ-6 у больных 2-й группы был ниже, чем у пациентов 1-й группы, на 23 \% (p=0,153), а у больных 3-й группы - на 31 \% (p=0,02) соответственно.

Выводы. Уровень провоспалительного ИЛ-6 при плановом стентировании коронарных артерий имеет тенденцию к снижению после установки стента, при этом более низкие показатели наблюдались в группах, в которых применялся в качестве анестетика раствор пропофола. Следует отметить, что в 3-й группе (где применяли безопиатную аналгезию) уровень ИЛ-6 через 10 мин после имплантации стента был статистически значимо ( $=0,02)$ ниже, чем в 1-й группе, в то время как между 1-й и 2-й группами статистически значимых различий по этому показателю не наблюдалось $(p=0,153)$. Этот факт можно объяснить применением раствора лидокаина у пациентов 3-й группы.

Ключевые слова: интерлейкин-6, плановое коронарное стентирование, аналгоседация, ишемическая болезнь сердца.

\section{D.O. Dziuba}

Shupyk National Medical Academy of Postgraduate Education, Kyiv, Ukraine

\section{Intraoperative dynamics of interleukin-6 levels during planned coronary stenting with different approaches to analgesic sedation}

The aim - to study the dynamics of the level of interleukin-6 (IL-6) under various drugs for analgesic sedation in the perioperative period of planned coronary stenting.

Materials and methods. This study was conducted from September 2018 to March 2020 in 90 patients with coronary heart disease. Patients were evenly divided into three study groups, depending on the drugs that were used for intraoperative analgosedation. Group 1 - slow intravenous administration of $10 \mathrm{mg}$ of diazepam solution and $100 \mu \mathrm{g}$ of fentanyl solution for induction and repeated administration of these drugs in the same dose to maintain anesthesia during surgery; group 2 - slow intravenous administration of the solution of fentanyl $1.5 \mathrm{mg} / \mathrm{kg}$ per induction and $1.5 \mathrm{mg} / \mathrm{kg}$ for $1 \mathrm{~h}$ to maintain analgesia, propofol solution was used to maintain a certain level of sedation; group 3 - slow intravenous administration of $1 \mathrm{mg} / \mathrm{kg}$ of lidocaine solution for induction, for sedation - propofol solution as well. All patients underwent recanalization as planned. In our study, the main study parameter was the level of IL-6 at the beginning of surgery and 10 minutes after stent implantation.

Results. When comparing operational indicators with the results that were obtained after stenting, in all groups, IL-6 indicators were lower than preoperative ones. The statistically significant difference between the studied index before surgery and 10 min after stent implantation was in the groups 2 and 3, in contrast to that in patients of the group 1: the level of IL-6 decreased to $30 \%$ in group $2(p=0.005)$ and in group $3(p=0.001)$.

Conclusions. The level of pro-inflammatory IL- 6 in routine coronary artery stenting tends to decrease after stent placement, with lower rates under propofol solution usage as an anesthetic. At the same time, in group 3 (where nonopioid analgesia was used) the level of interleukin- 6 at point 10 min after stent implantation was significantly lower than in first group. This fact might be explained by usage of lidocaine solution in patients of the third group.

Key words: interleukin-6, planned coronary stenting, analgosedation, coronary heart disease. 